sciendo Порівняльна професійна педагогіка 8(2)/2018

Comparative Professional Pedagogy 8(2)/2018

DOI: $10.2478 /$ rpp-2018-0016

Doctor of Science in Pedagogy, Full Professor, MARYNA GRYNOVA

V. H. Korolenko Poltava National Pedagogical University, Ukraine Address: 2 Ostrohradskyi St., Poltava, 36000, Ukraine E-mail: grinovamv@gmail.com

$\mathrm{PhD}$ in Pedagogy, Associate Professor, IRYNA KALINICHENKO

M. V. Ostrohradskyi Poltava Regional Institute for Advanced Teacher Training, Ukraine Address: 64-zh Sobornist St., Poltava, 36014, Ukraine E-mail: kalinichenko@poippo.pl.ua

\title{
TRENDS IN INCLUSIVE EDUCATION IN THE USA AND CANADA
}

\begin{abstract}
This paper deals with foreign experience of implementing inclusive education for children with special educational needs in the United States and Canada. Legal documents on inclusive education in foreign countries have been analyzed. The most relevant topic of American and Canadian scholars' researches on reforming special education is related to integration, that is gradual transition from exclusion of children with special educational needs to inclusion in comprehensive schools. Based on the analysis of American and Canadian researches on inclusive education it has been concluded that the changes in legislation and education policies of North American countries aim to achieve the highest level of progress in regular education and special education. It has been found that the development of inclusive education in Canada has undergone and is significantly influenced by the American education system. However, unlike the United States, Canada does not have a single legislative act that would standardize the introduction of inclusive education in the country. Each province has autonomous educational documents that specify the requirements for the inclusive education organization. It has been specified that in American schools, effective educational technology in inclusive education is a team approach when effective partner relationships are formed. A key to the successful integration of a child with special educational needs is the development of an individual curriculum. The Canadian education system, having its own national peculiarities that predetermine the differences in the course of education reforms, has always supported the democratic movement for civil rights and anti-discriminatory attitudes in US education. Foreign law and inclusive practice are an important source of ideas about possible ways to solve the problems of implementing inclusive education in Ukraine.
\end{abstract}

Keywords: children with special educational needs, inclusion, inclusive education, inclusive learning, special education.

\section{INTRODUCTION}

Nowadays, one can observe an increasing number of people who refuse to participate in social, political, economic and cultural life of their societies. Such a society is neither efficient nor safe. The first education for all movement originated after the conference on education for all was held in Jomtien, Thailand in 1990. Thus, a number of international and national non-governmental organizations, as well as UNESCO and other United Nation agencies aim to achieve the goal of this movement: to provide all children, 
young people and adults with the right to education. An inclusive approach is considered as a search for methods of transforming education systems to meet the needs of a wide range of learners. It chooses to respect and treat others based on the view that everyone enriches the community with their individuality, while a diverse school community is a resource for life and learning. Inclusive education aims to adapt school curriculum and educational environment to the needs of children with special educational needs. The process of defining the most optimal ways and means for implementing inclusive education is based on relevant legal, educational, methodical, psychological and pedagogical provisions, appropriate facilities and qualified human resources.

The Constitution of Ukraine, the Laws of Ukraine "On Education", "On Child Protection", the United Nation Convention on the Rights of Persons with Disabilities, the Conception of Inclusive Education Development, the Decree of the Cabinet of Ministers of Ukraine as of August 9, 2017 No 588 "On Amendments to the Procedure for the Organization of Inclusive Education in Comprehensive Schools" protect the rights of children with special educational needs.

One of the key ideological innovations of the new Law of Ukraine "On Education" is inclusive education. In the previous edition of the Law "On Education", inclusion has not been considered. Individuals with special needs are mentioned only in the context of providing students with special needs with nutrition, or teacher's loss of working capacity. The law states that each school should be inclusive in its philosophy. This means readiness to accept every child at any time, striving to create the most favourable environment for their potential development.

Inclusive education is based on the idea of an adaptive school that takes into account individual characteristics of each child (S. Alokhina); the strategy for joint learning of all children, which allows equalizing the initial conditions under which each child can obtain education (Yu. Melnyk); the system of educational services offered to students with special educational needs in comprehensive schools (S. Semak), which is based on the principle of ensuring the main right of the child to education and the right to attend nearby comprehensive schools (O. Kryvonosova); the process of learning and learning outcomes of students with special educational needs, who study within regular educational environment by special programmes, creatively adapted methods and teaching methodologies (V. Bondar).

Many researchers believe that inclusive education should not be considered outside the relevant context, and there is no single definition of "inclusive education". The context in which it is realized is determined by a set of geographical, demographic, cultural and linguistic characteristics and factors of the country concerned.

Therefore, at the present stage of reforming Ukrainian education, the role of theoretical search and researches on foreign experience in organizing and implementing inclusive education for children with special educational needs is of great importance.

THE AIM OF THE STUDY

The paper aims to theoretically analyze the trends in development of inclusive education in the USA and Canada.

THEORETICAL FRAMEWORK AND RESEARCH METHODS

The origination and development of inclusive education in North American countries have been studied by S. Alokhina, J. Andrews (2000), V. Bondar, E. Danilavichiutie, L. Danylenko, A. Gartner (1997), A. Kolupaieva (2009), O. Kryvonosova, D. Lipsky (1997), J. Lupart (2000; 2010), S. Lytovchenko, Yu. Naida, 
sciendo Порівняльна професійна педагогіка 8(2)/2018 Comparative Professional Pedagogy 8(2)/2018

M. Orlansky, T. Sak (2010), L. Savchuk, N. Sofii, Ye. Synova, O. Taranchenko, C. Webber (2010), S. Wilks, M. Winser, V. Zasenko et al. The problem of training teachers for inclusive education has been explored by O. Akimova, Ya. Baranets, I. Demchenko, O. Demianchuk, V. Hladush, O. Martynchuk, S. Semak, A. Shevtsov, M. Zakharchuk et al.

To achieve the established aim of our research, we have used such methods as theoretical analysis and generalization of foreign scientific sources and systematization of American and Canadian experience in organizing and implementing inclusive education.

\section{RESULTS}

Over the last few decades, developed countries have undergone significant changes in the attitude towards low-mobility groups of the population and providing quality educational services for children with special educational needs. Therefore, an inclusive model of education is becoming ever more acute. In view of the above, it is rather imperative to study foreign experience of those countries that have already achieved significant progress on this matter. Foreign law and inclusive practice are an important source of ideas about possible ways to solve the problems of implementing inclusive education in Ukraine.

In most countries, the right to education for people with special educational needs is enshrined in legal acts. This may be a constitutional or general right governed by the country, mandatory or recommendatory provisions of the law. In 1975, the United States passed the Education for All Handicapped Children Act (EAHCA), which ensured equal opportunities to receive "free and quality regular education within a favourable environment". In 1990, the Act was accordingly renamed the Individuals with Disabilities Education Act (IDEA). Its programmes were redesigned to improve the support given to male and female students with different capabilities, particularly in the areas of transferring additional technologies. The Act was applied in all spheres of life, namely, education, employment, medicine, leisure, and only exceptions were private schools and religious organizations.

The Federal Law, adopted in 1990, and the Act on Training of Individuals with Mental Disorders, approved in 1995, have become the legal basis for reforming the system of education for children with special educational needs and organizing inclusive education in mainstream schools. In addition, the fact that there appeared a category of children with learning difficulties has contributed to introducing inclusive education in schools. Thus, these children do not need to attend specialist institutions, and they can overcome their problems among their peers if provided with certain services and all appropriate assistance. The Act permits a variety of conditions for them to be provided, which is consequently implemented in different states of the country. However, some problems always occur when implementing this paragraph of the Act, since providing appropriate services and meeting special educational needs of these children require significant funding, which is difficult to receive in some cases. In fact, the American education has been accompanied by fierce and politicized controversy around concepts such as new education, advanced education, high progress rates, how to choose a good school, as well as the integration of children with special needs in mainstream schools over the last century.

Among the most prestigious special education schools, there is a confrontation between those who seek to preserve the already existing and hard-won modifications in traditional special education programmes and those who seek a full-scale restructuring of regular and special education into a more unified regular education system. Such controversy leads to profound differences, which endangers the very philosophical and pedagogical foundation of special education. In addition, beyond considerable debates on special education and education for gifted children, there appears to be a wider issue of the role of special education in the context of reforming regular education (Lupart, \& Webber, 2010). 
It must be noted that, despite the principles of decentralization in education policy, each state has special boarding schools, where mostly orphan children with visual disabilities live. They can also attend special classes in nearby mainstream schools, receiving rehabilitation services at a special school. These special boarding schools serve as resource centers, which provide teaching, methodological and rehabilitation services in a particular area.

In American schools, a team approach is an effective educational technology in inclusive education, since effective partner relationships are formed. Successful integration of a child with special educational needs consists in developing an individual curriculum. The individual curriculum is characterized by a well-developed structure of educational goals and objectives that are achieved by applying appropriate adaptations and modifications of the standard curriculum, which enables such a child to be included in the classroom.

The Canadian education system, which has its own national peculiarities predetermining the differences in the course of educational reforms, has always supported the democratic movement for civil rights and anti-discriminatory attitudes in US education. Thus, since the 1980s, the Canadian system of regular education has launched powerful school reforms and school restructuring. It has led to several initiatives, including the initiatives for enhancing school efficiency, improving school environments, peer teaching, as well as increasing teacher professionalism. In addition, the following concepts such as integration, normalization, natural and social justice, inclusion in prevalent attitudes (mainstreaming), the least restrictive environment, the idea of regular education have significantly influenced the process of transforming conceptual views on the system of education for children with special needs in the country. Canadian researchers indicate that the idea of restructuring and merging regular and special education together has marked a gradual but steady trend towards inclusion. Such Canadian educational trends in development of inclusive education for children with special educational needs are somewhat followed by the reforms in the American education system (Malyshevska, 2016).

The Canadian Constitution of 1981 mentions human rights, including those relating to the issue of different capabilities. The Minister of Education and school administration are responsible for including all students in the education process and providing them with special educational programmes and free tuition.

The main education Acts such as "School Law" and "Standards for Special Education" define the basic conditions under which inclusive education of children with special needs should be realized, which is, above all, an individual approach to each child, providing the appropriate support of their education and involving parents as equal participants in the education process. Planning the coordination and outlining the prospects for training students with special educational needs occur while creating an individual curriculum. This normative document contains assessment data; the current level of educational progress; students' strengths and weaknesses; the procedures for assessing students' progress; additional services and support, including medical assistance, if necessary; relevant medical information; necessary architectural changes and adaptation to the environment; additional teaching aids and facilities; intermediate planning; a short report at the end of each academic year. Based on the individual curriculum, if necessary, one can modify some educational programmes for students with special needs. These students receive additional support from various specialists, mainly school support services. In addition, students who suffer from psychophysical problems can interact with assistants or teacher assistants (Kolupaieva, 2009). 
sciendo Порівняльна професійна педагогіка 8(2)/2018

Comparative Professional Pedagogy 8(2)/2018

In 1997, Michael Peterson (PhD, Professor and Coordinator of the Wayne State University, Michigan), together with a small group of colleagues joined their efforts to create an inclusive concept for the school. They identified the "eight principles of approach" to the essence of a new school, now called "integral education": empowering citizens to participate in a democratic society, creating an inclusive environment, authentic and multilevel learning, building communities, providing support in learning and establishing partnerships with parents and local communities. The researchers have created the Whole Schooling Consortium, which is now an international network and includes teachers, educational institutions, parents, administrators and lecturers (Lorman, Deppeler, \& Kharvi, 2010).

It must be noted that Canada's specialist institutions have not been completely eliminated due to education reforms. This indicates a well-considered policy, which is aimed at overcoming segregation and introducing inclusive education for children with special educational needs. Special education specialists express different views on the conceptual framework for teaching students with special educational needs and the potential for using inclusive education. However, the main concern is the possibility of losing experience and resources of special education that have been accumulated for decades.

The supporters of the Regular Education Initiative state, "too many students are described as having specific developmental disadvantages, in particular it relates to children with learning difficulties; too much time is spent on determining the belonging to a certain category, but too little attention is paid to how to meet educational needs of students; specialized programmes, which involve partial exclusion of students from the normal environment, although their effectiveness should still be documented; fragment learning and teaching; individual classes for students with special needs are morally unjustified" (Audette, \& Algozzine, 1992).

In Canada, there are school boards that play an important role in designing and reviewing policies that support better educational practices, including inclusive ones. Provincial governments delegate most of their education management responsibilities to local school boards. These boards are regarded as responsible for school activities. So, school boards are responsible for: setting priorities for the system taking into account the needs of community members, available resources and achievements of educational practices; setting goals within the jurisdiction to ensure educational progress; adopting the annual budget for the school system; creating policies on human resources management, which meet the objectives of the community; communicating with community members and human resources; providing education and enhancing community members' awareness of education issues; collecting information to make the right decisions; adopting arbitration awards in political disputes (Bleiz, Chornoboi, Kroker, Strat, \& Krasiukova-Ennz, 2012).

The concepts of "inclusion", "inclusive education" acquire different meanings depending on the context influenced by the country's policy, economic situation, traditions, globalization processes and social conditions under which the education system develops. L. Florian (2014) suggests there are three types of definitions in a global context that have evolved in different parts of the world (the United States, Canada and the United Kingdom) and reflect different ideas of inclusion (pp. 287-288).

Canadian scholars focus on child-centered approach underlying the organization of inclusive education and considering the difference as a resource, not a drawback. This approach leads to defining inclusion as "the possibility of complete significant integration" (Alberta), "the principle and the right to equal access" (British Columbia), "philosophy, vision and belief" (Quebec), "the mode of thought" (Manitoba), "attitude, value systems" 
(Nova Scotia), "the unity of ideas and philosophy" (New Brunswick). Inclusive education is viewed as "a way of thinking and action" (Alberta), "the embodiment of opinion" (Nova Scotia). The education system as a system of services is characterized by such verbs as "ensure", "implement", but common concepts defining "inclusion" and "inclusive education" prove potential identification of these notions. The research proves L. Florian's view that inclusive education in Canada is child-centered (Bondar, 2017).

The Index for Inclusion is a tool for monitoring the processes of creating and developing an inclusive educational environment in an educational institution. Analyzing the situation in schools based on these materials one can rapidly outline the guidelines, which will direct the process of promoting its inclusive development. Methodological approaches to implementing the Index for Inclusion are based on the knowledge and experience teachers, children and their families possess with regard to educational environment in their institution and the ways to improve it. This comprehensive document allows determining whether the school is indeed inclusive and how it can minimize the impact of any factors that result in exclusion. The Index for Inclusion materials are used in Canada and the United States, which allow these countries to continuously analyze and improve inclusive practice, culture and policy of schools, enhance educational progress of all students.

It must be noted that the development of inclusive education in Canada has undergone and is significantly influenced by the American education system. However, unlike the United States of America, Canada does not have a single legislative act that would standardize the implementation of inclusive education in the country. Each province has autonomous educational documents that specify the requirements for the inclusive education organization.

\section{CONCLUSIONS}

So, theoretical analysis of American and Canadian scientific literature proves that the changes in legislation and education policies of North American countries aim to achieve the highest level of educational progress in regular education and provide children with special educational needs with the opportunity to obtain special education. Indeed, this experience is rather relevant for Ukraine and can serve as a good example when implementing the basic principles of inclusive education stated in the Law of Ukraine "On Education".

Prospects for further researches include searching for new forms of teacher training in relation to the use of information and communication technologies when organizing distance learning for children with special educational needs, as well as new software for implementing the corrective and developmental component.

\section{REFERENCES}

1. Audette, B., \& Algozzine, B. (1992). Free and appropriate education for all students: total quality and the transformation of American public education. Remedial and Special Education, 13 (6), 8-18.

2. Barth, R. S. (1990). Improving schools from within: teachers, parents and principles can make a difference. San Francisco, CA : Jossey-Bass.

3. Bleiz, D., Chornoboi, E., Kroker, S., Strat, E., \& Krasiukova-Ennz, O. (2012). Rozvytok polityky inkliuzyvnykh shkil. Intehrovane planuvannia posluh, yikh nadannia ta finansuvannia v Kanadi. Kyiv: Palyvoda A. V. 
4. Bondar, T. I. (2017). Inkliuzyvna osvita Kanady: poniatiino-katehorialnyi aparat. Naukovyi visnyk Uzhhorodskoho universytetu. Seriia: "Pedahohika. Sotsialna robota”, 1 (40), $27-30$.

5. Florian, L. (2014). What counts as evidence of inclusive education? European Journal of Special Needs Education, 29 (3), 286-294.

6. Fullan, M. G. (1993). Change forces. Probing the depths of educational reform. London: The Falmer Press. Sammit-Knyha.

7. Kolupaieva, A. A. (2009). Inkliuzyvna osvita: realii ta perspektyvy. Kyiv:

8. Lipsky, D. K., \& Gartner, A. (1997). Inclusion and school reform: transforming America's classrooms. Baltimore, MD: Brooks.

9. Lorman, T., Deppeler, D., \& Kharvi, D. (2010). Inkliuzyvna osvita. Pidtrymka rozmaittia u klasi: praktychnyi posibnyk. Kyiv: SPD-FO Parashyn I. S.

10. Lupart, D., \& Webber, Ch. (2010). Shkilna reforma v Kanadi: perekhid vid rozdilnykh system osvity do inkliuzyvnykh shkil. Defektolohiia, 1, 6-11.

11. Malyshevska, I. A. (2016). Zarubizhnyi dosvid inkliuzyvnykh tendentsii v osviti. Visnyk Cherkaskoho universytetu, 10, 102-107.

12. Sak, T. V. (2010). Indyvidualnyi navchalnyi plan uchnia $\mathrm{z}$ osoblyvymy osvitnimy potrebamy v inkliuzyvnomu klasi. Defektolohiia, 3, 12-16. 